\title{
Chlamydia pneumoniae-Induced IFN-Gamma Responses in Peripheral Blood Mononuclear Cells Increase Numbers of CD4+ but Not CD8+ $T$ Effector Memory Cells
}

\section{Tamar A Smith-Norowitz Sarah Shidid \\ Yitzchok M Norowitz Stephan Kohlhoff}

Department of Pediatrics, Division of Infectious Diseases, State University of New York Downstate Medical Center, Brooklyn, NY, I I203, USA
Correspondence: Tamar A Smith-Norowitz SUNY Downstate Medical Center, Department of Pediatrics, Box 49, 450 Clarkson Ave., Brooklyn, NY, I 1203, USA Tel + I 718 270-1295

Fax + I 718 270-3289

Email tamar.smith-norowitz@downstate. edu
Background: Chlamydia pneumoniae causes respiratory infection in adults and children. Previous studies in our laboratory identified significantly higher in vitro $\mathrm{T}$ lymphocyte responses to $C$. pneumoniae in children with asthma compared to healthy controls which may indicate the presence of T effector memory (TEM) lymphocytes.

Aim: In the present study, healthy subjects were screened for the presence of TEM cells and their cytokines. CCR7 negative effector TEMs may indicate persistent infection with C. pneumoniae.

Methods: Peripheral blood mononuclear cells (PBMC) $\left(1 \times 10^{6} / \mathrm{mL}\right)$ from adult nonasthmatic subjects were infected for $1 \mathrm{~h} \pm C$. pneumoniae $\mathrm{TW}-183$ at a multiplicity of infection $(\mathrm{MOI})=0.1$ and cultured $(48 \mathrm{hrs})$. Distributions of lymphocytes $(\mathrm{CD} 4+, \mathrm{CD} 8+$ ) and TEM cells (CD4+CCR7+CD45RA+CD154+, CD8+CCR7+CD45RA+CD154+) were determined. Levels of intracellular interleukin (IL)-2, IL-4, and interferon (IFN)-gamma were measured (flow microfluorimetry); IFN-gamma was measured in supernatants (ELISA). Results: C. pneumoniae infection led to a decrease in numbers of CD8+ TEM and CD8 + CD154+ cells; CD4+TEM and CD4+CD154+ cells did not change. Numbers of TEM cells (CD4+IL-2+, CD8+ IL-2+) also decreased. However, number of TEM cells (CD4+IL4-+, $\mathrm{CD} 8+$ IL-4+) and (CD4+ IFN-gamma+, CD8+IFN-gamma + ) did not change. When stratified according to IFN-gamma+ status, numbers of CD4+ IL-2+ and CD4+IL-4+ TEMs increased; CD8+IL-2+ and CD8+ IL-4+ TEMs decreased.

Conclusion: $C$. pneumoniae-induced PBMC IFN-gamma + responses increased numbers of CD4+ IL-2+ and CD4+IL-4+ TEM cells, while CD8+IL-2+ and CD8+IL-4+ TEMs decreased. Production of IFN-gamma by $C$. pneumoniae infected PBMC should be further studied as a biomarker of persistent infection in humans.

Keywords: C. pneumoniae, T effector memory lymphocytes, interleukin-2

\section{Introduction}

Chlamydia pneumoniae (C. pneumoniae) is an intracellular bacterium that infects humans; it causes respiratory infections ${ }^{1,2}$ in asthmatic and non-asthmatic subjects. $^{2-5}$ C. pneumoniae activation of immune cells (eg, monocytes/macrophages, epithelial cells) in vitro produce cytokines that may contribute to the pathology observed in asthma; protective immune responses against respiratory infection are also reduced. ${ }^{2}$ However, in children with chronic respiratory disease 
(CRD), C. pneumoniae infection triggers the production of pathogen-specific Immunoglobulin (Ig) E and contributes to inflammatory responses. ${ }^{6} \mathrm{C}$. pneumoniae infection treatment includes tetracyclines or erythromycin; tetracyclines have been reported to have beneficial effects in patients with asthma. ${ }^{2,7,8}$

Previous studies in our laboratory demonstrated that C. pneumoniae was present in $11 \%$ of wheezing children. ${ }^{3}$ Other studies in our laboratory found an association of specific IgE responses to C. pneumoniae in $86 \%$ of $C$. pneumoniae positive children with asthma compared with $9 \%$ of culture positive patients with pneumonia who did not have asthma., ${ }^{9,10}$ Prior literature reported that C. pneumoniae could enter a persistent state in vitro spontaneously, after treatment with cytokines such as interferon (IFN)-gamma, antibiotics or nutrient restriction. ${ }^{11-13}$ Following acute respiratory infection, long-term culture positivity in nasopharyngeal (NP) specimens can occur for up to 6 months, ${ }^{3,14}$ and has been associated with continuing clinical symptoms of asthma. ${ }^{3}$

Diagnostic testing for $C$. pneumoniae using NP specimens may underestimate persistent infection; the presumed focus of infection in asthma is the lower airway. The chlamydial load may also be low. Other studies reported that after acute infection with $C$. pneumoniae, positive lymphocyte proliferation and secretion of IFNgamma were detected in vitro. ${ }^{15}$ In that study, lymphocyte responses to $C$. pneumoniae declined following the acute phase of infection. ${ }^{15}$ Persistence of IFN-gamma responses was observed up to 16 weeks following acute infection in a subset of $C$. pneumoniae positive subjects. ${ }^{15}$

Earlier studies in our laboratory demonstrated important immunological differences between asthmatics and nonasthmatic subjects in regard to the host response to C. pneumoniae. $^{16}$ In peripheral blood mononuclear cells (PBMC) obtained from adult asthmatics, C. pneumoniae stimulation induced predominant production of T helper (Th) 2 responses and IgE. ${ }^{16}$ These responses may indicate chronic inflammation, which can be related to persistent infection. In addition, we found that $C$. pneumoniae-induced IFN- $\gamma$ production in vitro was more prevalent in pediatric patients with asthma compared with non-asthma; this is consistent with the presence of circulating T memory lymphocytes. ${ }^{17}$ Since cellmediated immunity (CMI) of the Th1 type is required for optimal control of chlamydial infections in vivo one might expect persistent infection in individuals with decreased Th1 and/or increased Th2 type responses. ${ }^{18,19}$ However, the observation of a positive IFN-gamma PBMC response in the presence of $C$. pneumoniae-specific T effector memory cells (TEMs) would indicate persistent C. pneumoniae infection.

Prior literature has reported that circulating memory cells responsive to chlamydial antigens are found in humans; ${ }^{19,20}$ they are specialized to handle infection arising within peripheral organs due to their cytotoxicity and ability to localize to tissues. TEMs may play a role in immunoprotection and immunopathology following recognition of $C$. pneumoniae-infected cells. Effector memory $\mathrm{T}$ lymphocytes have been demonstrated in other human latent infections (eg, tuberculosis). ${ }^{21}$ Thus, the presence of TEMs may indicate either past or persistent infection depending on their characteristics.

The aim of the current study was to expand the existing knowledge of effector memory $\mathrm{T}$ lymphocytes through identification of $C$. pneumoniae specific CD4+ and CD8+ TEMs and their cytokines (IL-4, IL-2, IFN-gamma) in C. pneumoniae-stimulated PBMC in non-asthmatic subjects without respiratory illness. When stratified according to IFN-gamma+ status, numbers of CD4+ IL-2+ and CD4 +IL-4+ TEMs increased while CD8+IL-2+ and CD8+ IL-4 + TEMs decreased.

\section{Materials and Methods}

\section{Study Population}

The study population consisted of patients ( $\geq 18$ years old) who visited the outpatient clinic of the Department of Medicine at SUNY Downstate Medical Center (Brooklyn, NY) between June and August 2019. The inclusion criteria were: (1) non-asthmatic adult without clinically defined persistent asthma symptoms, ${ }^{22}$ (2) low serum IgE levels $(<100 \mathrm{IU} / \mathrm{mL})$ and (3) no other chronic or severe respiratory disease (eg, tuberculosis, emphysema, bronchiolitis or diffuse lung disease). Exclusion criteria included subjects with asthma, severe respiratory disease or human immunodeficiency virus (HIV)-1. All subjects had an NP swab tested for C. pneumoniae (determined by PCR), and peripheral blood $(10 \mathrm{~mL})$ was collected. All demographic and clinical data were obtained from electronic medical records (EMRs) and reviewed at the time of enrollment. The study was approved by the SUNY Downstate Medical Center Institutional Review Board (Brooklyn, NY) and human studies adhered to the World Medical Association Declaration of Helsinki. Written informed consent for participation and publication was obtained from all participants. 


\section{Immunoglobulin Determination: Total Serum lgE}

Total serum IgE levels were determined in serum using the UniCap Total IgE fluoroenzyme immunoassay (Pharmacia and Upjohn Diagnostics, Freiburg, Germany) as previously described. ${ }^{17,23}$ Tests were performed in the Clinical Diagnostic Laboratory at SUNY Downstate Medical Center (Brooklyn, NY).

\section{Preparation of $C$. pneumoniae}

C. pneumoniae TW-183 (ATCC; Manassas, VA) was propagated in HEp-2 cells as previously described. ${ }^{24,25}$

\section{Cell Cultures}

PBMC were separated from blood on a Ficoll-Paque (GE Healthcare, Sweden) gradient (density 1.077) and put into cell culture as previously described, ${ }^{23}$ at $37^{\circ} \mathrm{C}$ in cRPMI medium in a humidified 5\% $\mathrm{CO}_{2}$ atmosphere for 2 days. Cell viability was determined at 0 and $48 \mathrm{hrs}(>98 \%$ and $95 \%$, respectively), in the absence of infection with C. pneumoniae.

\section{In vitro Infection with $C$. pneumoniae}

Following a $2 \mathrm{hr}$ incubation to allow adherence, cell cultures were infected with C. pneumoniae (by adding purified EB for $1 \mathrm{hr}$ ), or mock-infected (MI) for $48 \mathrm{hrs}$ (IFN-gamma) at $37^{\circ} \mathrm{C}$ in cRPMI in a humidified $5 \% \mathrm{CO}_{2}$ atmosphere, as previously described. ${ }^{23}$ The cytokine assay (IFN-gamma) was run using supernatants collected from above cultures. The multiplicity of infection (MOI; 0.1) and time points (48h p.i. for cytokines ${ }^{26}$ used for analysis were selected based on kinetic and dose response studies (using MOI of 0.01-10) for optimization of the assay. Two types of controls were used in infection experiments: identical volumes of heat-inactivated purified C. pneumoniae ${ }^{26}$ and identical volumes of HEp-2 cell cultures not containing any bacteria processed the same way as the purified C. pneumonia $e^{25}$ based on dose-response experiments.

\section{Cytokine (IFN-Gamma) Determination: ELISA}

For the in vitro quantitative determination of human cytokine content in cell culture supernatants, a solid-phase sandwich ELISA assay was performed using the Human IFN-gamma ELISA kit (Abcam, Cambridge, MA), according to the manufacturer's recommended procedure. Cell culture supernatants were collected at $48 \mathrm{hr}$ p.i. by centrifugation, and samples were stored at $-80^{\circ}$ until analysis. Sensitivity for cytokine assay was $<15.0 \mathrm{pg} / \mathrm{mL}$.

\section{Quantitative Real-Time Polymerase Chain Reaction ( $q P C R$ ) of Bacteria in Swabs and Cultures}

Extractions of bacterial DNA from NP swab specimens ${ }^{27}$ and PBMC were performed using a QIAAmp DNA Mini-Kit (Qiagen Inc., Valencia, CA), according to manufacturer's recommendations, as previously described. ${ }^{27,28}$ Specimens were tested for the presence and quantification of C. pneumoniae and M. pneumoniae DNA, using TAQMan technology-based qPCR (Light Cycler 2.0 platform; software version 4.0, Roche Diagnostics Corp, Indianapolis, IN), as previously described. ${ }^{27,28}$ A specimen from either nostril that was positive for $C$. pneumoniae defined a positive result.

\section{Determination of Cell Surface Markers}

Single- and dual-color immunophenotyping of lymphocytes was performed at $48 \mathrm{hr}$ as described in our previous studies $^{16,29}$ with modifications for intracellular staining. Gating strategies included forward and side scatter, single parameter histograms, two-parameter density plots, and back-gating to confirm gating strategies. Antibodies (Abs) used included mouse anti-human monoclonal antibodies (mAbs) (of the IgG1 isotype): fluorescein isothiocyanate (FITC)-conjugated CD3, CD14, CD45RO, CD45RA, CD154, CCR7, IL-2, IL-4, IFN-gamma; phycoerythrin (PE)-conjugated $\mathrm{CD} 8$ and $\mathrm{CD} 4-$ perCP; and the following Simultest (FITC/PE-conjugated) reagents: CD4/CD8, CD3/ CD19. All mAbs were purchased from BD Biosciences (San Diego, CA) or R\&D Systems (Minneapolis, MN), and titrated to obtain maximum staining efficiency according to manufacturer's recommendation. Flow cytometric analysis was performed on a Coulter Epics XL/MCL Flow Cytometer using System II software (Coulter, Miami, FL) and CytoComp (Coulter). The total numbers of lymphocytes were calculated from the white blood cell (WBC) count (total lymphocytes $/ \mathrm{mm}^{3}$ or percentage total lymphocytes).

\section{Determination of $C$. pneumoniae Activated TEMs}

TEMs are commonly found in the presence of persistent viral infections and can be characterized by expression of either CD4, CD8, CD45RO, CD45RA, CCR7, CD154, IFN-gamma, IL-2, IL-4. Based on recent experiments, ${ }^{30}$ 
we established a cut-off $(50 \%$ increase in TEMs $48 \mathrm{hrs}$ post-stimulation).

\section{Statistical Analysis}

Data are expressed as means \pm SD unless otherwise indicated. All statistical analyses were performed using Windows v.12.0 software (SPSS Inc., Chicago, IL).

\section{Results}

\section{Study Population}

The population studied included blood and plasma samples from five non-asthmatic adult patients: 2 males (ages 24,51 ) and 3 females (ages 51, 59, 65). Total serum IgE levels were low $(<100 \mathrm{IU} / \mathrm{mL})$ in all subjects. Subjects tested negative for $C$. pneumoniae.

\section{Phenotypic Determination of $C$. pneumoniae-Activated TEMs .}

TEMs are cells that are either CD4+ or CD8+ and are CCR7-, CD45 RO+ and CD154+. These T cells are activated by known antigen (ie, $C$. pneumoniae). We then characterized the cytokine profile of the $C$. pneumoniaeactivated CD4+154+ and CD8+CD154+ T cells by analyzing distributions of IL-2+, IL-4+ and IFN-gamma+ cells.

\section{Total CD4+ and CD8+ TEMs and CDI54 + TEMs}

C. pneumoniae infection (48 hr) led to a decrease in average numbers of CD8+ TEM and CD8+CD154+ cells (50\%, 33\%, respectively) (Figure $1 \mathrm{~A}$ and $\mathrm{B})$; numbers of CD4+TEMs and CD4+CD154+ cells did not change (at
$1: 10$ or $1: 100)$ (Figure $1 \mathrm{~A}$ and $\mathrm{B}$ ). However, numbers of CD4+CD154+ TEMs were 4-fold higher than numbers of CD8+CD154+ TEMs (Figure 1B).

\section{CD4+ IL-2+, CD8+ IL-2+ TEMs}

C. pneumoniae infection (48 hr) led to a decrease in numbers of CD4+IL-2+ and CD8+ IL-2+ TEMs ( 27\%, $50 \%$, respectively) (Figure $2 \mathrm{~A}$ )

\section{CD4+IL-4+, CD8+IL-4+ TEMs and CD4 +IFN-Gamma+, CD8+IFN-Gamma+ TEMs}

C. pneumoniae infection (48 hr) did not change numbers of CD4+IL-4+ or CD8+IL-4+ TEMs. Numbers of CD4+ IFN-gamma+ and CD8+IFN-gamma+ were low and did not change (at 1:10 or 1:100) (Figure 2B and C).

\section{C. pneumoniae-Induced IFN Gamma Levels}

IFN-Gamma Levels in Supernatants

C. pneumoniae induced IFN-gamma responses were measured on days 3,5 and 7 post-infection. PBMC were infected using 2 different concentrations of C. pneumoniae $(1: 10,1: 100)$. At each time point, IFNgamma levels were higher at the 1:10 compared with 1:100 concentration. IFN-gamma levels ranged from $204 \mathrm{pg} / \mathrm{mL} \pm 85$ to $541 \mathrm{pg} / \mathrm{mL} \pm 467$, with levels peaking on day 5 post-infection (Figure 3). IFNgamma levels $(1: 10)$ were $>50 \%$ higher on day 5 , than on day 3 .
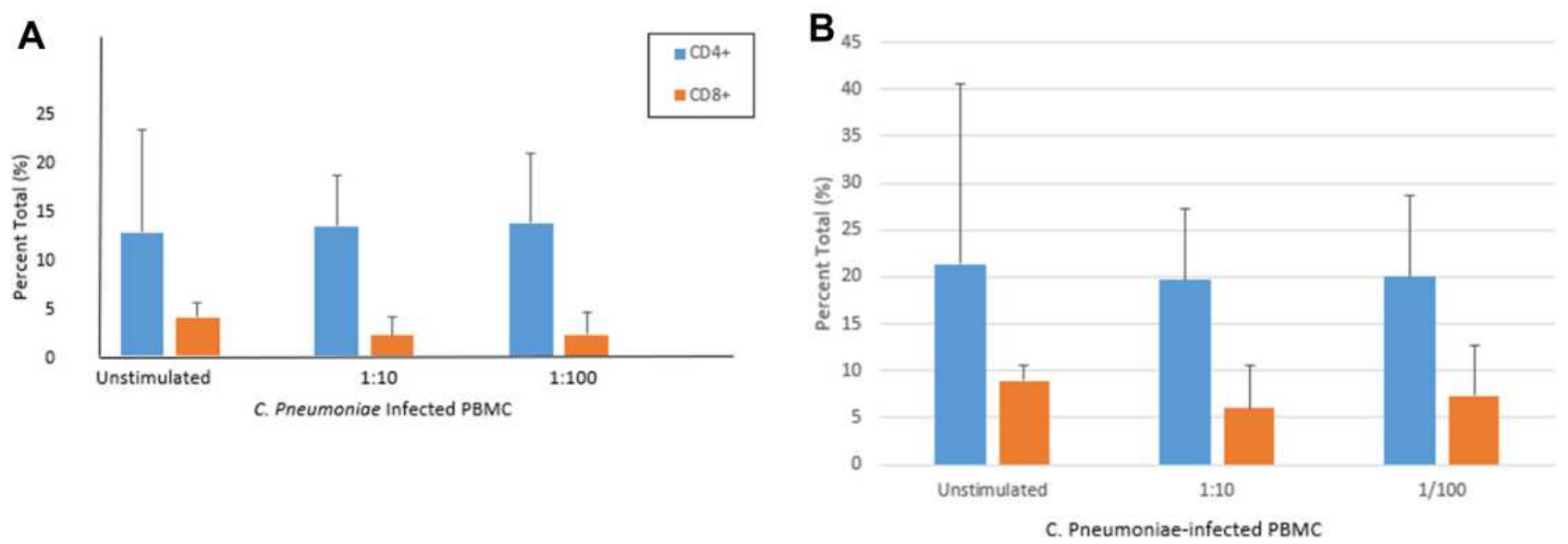

Figure I Phenotypic determination of $C$. pneumoniae-activated TEMs. (A) Total CD4+ and CD8+ TEMs. (B) CD4+CDI54+ and CD8+CD4+ TEMs. See materials and methods. Blue box: CD4+ T cells. Red box: CD8+ T cells. 


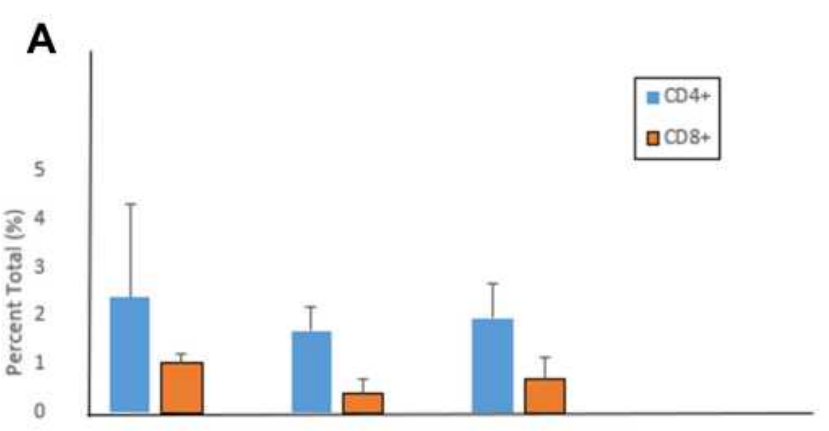

c. Pneumoniae Infected PBMC

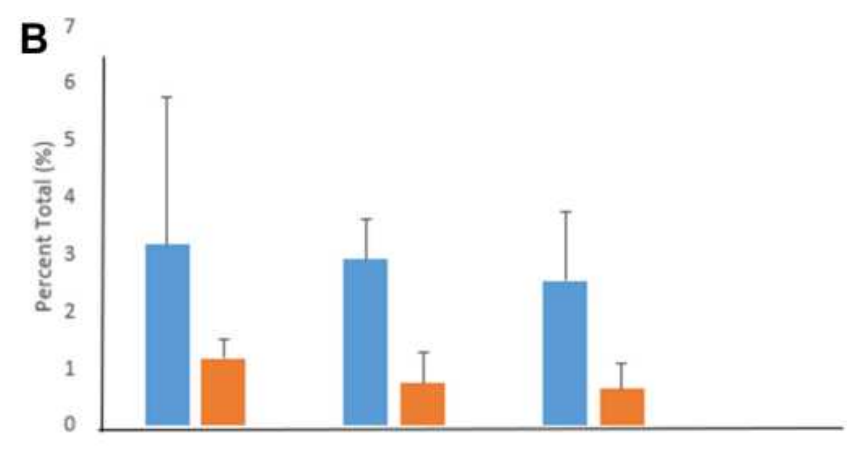

C. Pneumoniae Infected PBMC

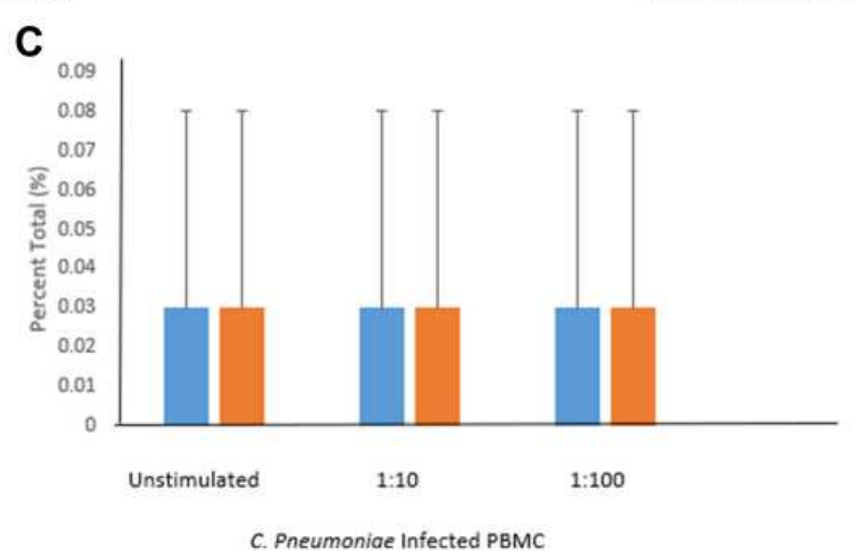

Figure 2 Phenotypic determination of C. pneumoniae-activated TEMs. (A) CD4+ IL-2+, CD8+ IL-2+ TEMs. (B) CD4+IL-4+, CD8+IL-4+ TEMs. (C) CD4+IFN- $\gamma+$, CD8 + IFN- $\gamma+$ TEMs. See materials and methods. Blue box: CD4+ T cells. Red box: CD8+ T cells.

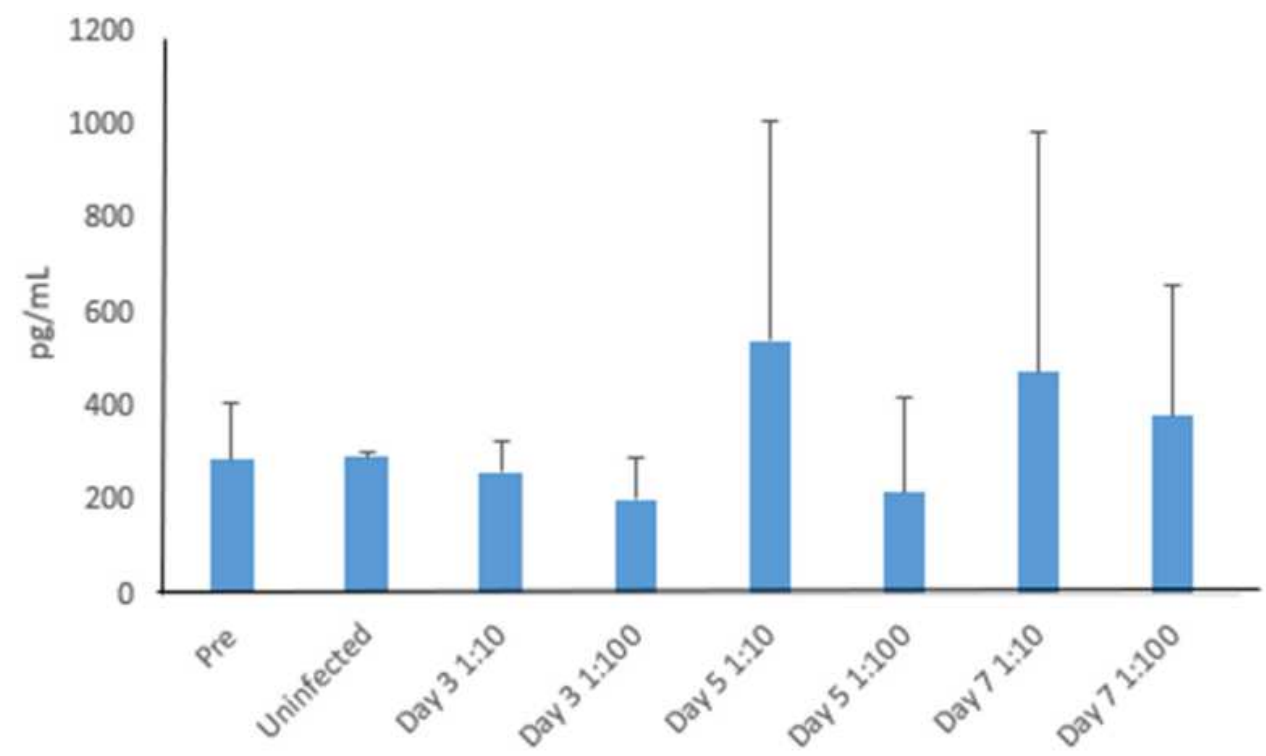

Figure 3 C. pneumoniae-induced IFN- $\gamma$ levels in cell culture supernatants. C. pneumoniae induced IFN- $\gamma$ responses were measured on days 3,5 and 7 post-infection (ELISA) $(\mathrm{N}=4)$. See materials and methods. Data are reported as $\mathrm{pg} / \mathrm{mL}$.

\section{IFN-Gamma Levels Stratified According to CD4+} and CD8+ TEMs

In each subject, IFN-gamma responses were then stratified according to $\mathrm{CD} 4+\mathrm{CD} 154+$ and $\mathrm{CD} 8+\mathrm{CD} 154+$ TEMs.
Numbers of CD4+CD154+ and CD8+CD154+ TEMs were elevated in $25 \%$ of subjects (Figure $4 \mathrm{~A}$ ). In subject with high IFN-gamma response (represented in Figure 4A, subject 1), numbers of CD4+ CD154+ and CD8+CD154+ TEMs levels 

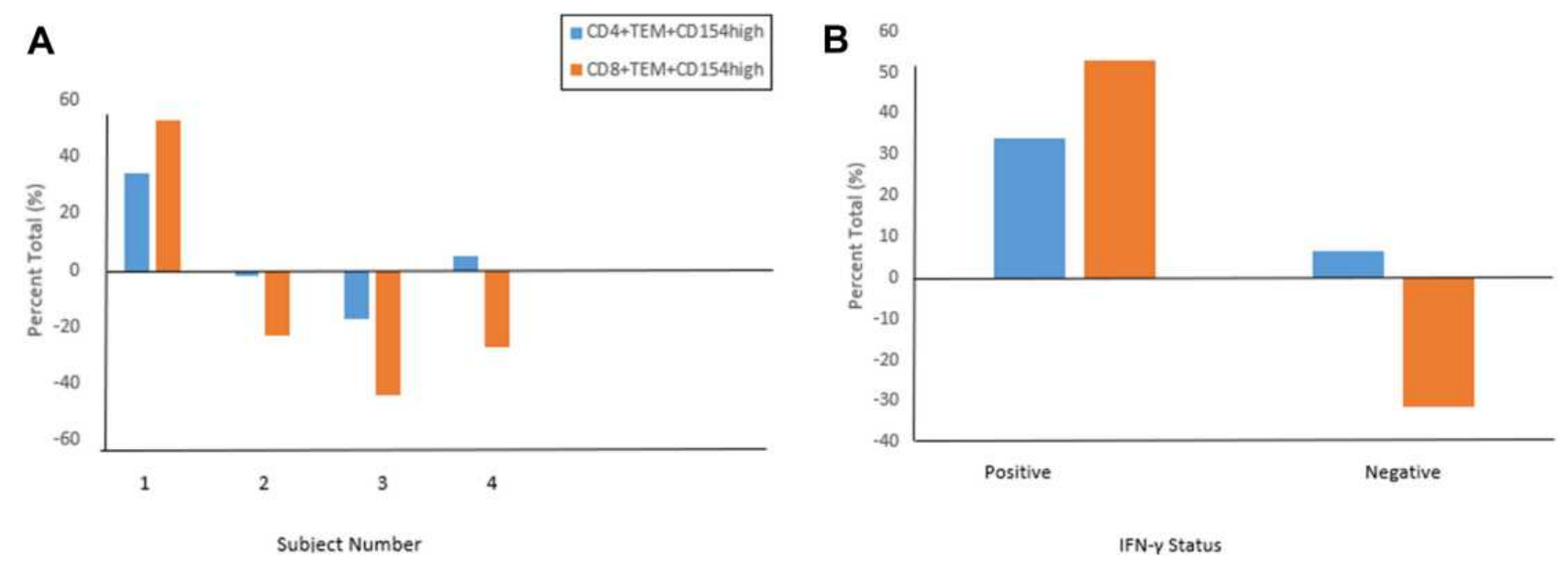

Figure 4 C. pneumoniae-induced IFN- $\gamma$ levels stratified according to CD4+ and CD8+ TEMs. (A) Numbers of CD4+ 154+ and CD8+CDI54+ TEMs (N=4), (B) numbers of CD4+154+ and CD8+CDI54+ TEMs in representative IFN- $\gamma$ positive and IFN- $\gamma$ negative subject. See materials and methods. Blue box: CD4+ T cells. Red box: CD8+ T cells.

were higher than in subject with low IFN-gamma response (represented in Figure 4A, subject 4) (Figure 4B).
(Figure 6A and B). Numbers of CD4+IFN-gamma+ and CD8+IFN-gamma + TEMs were low and did not change.

\section{CD4+ and CD8+ TEMS Stratified According to IFN-Gamma Levels in Subjects IFN-Gamma Positive}

Subject who was IFN-gamma positive had an increase in CD4+IL-2+ and CD4+IL-4+ TEMs (Figure 5A), while numbers of CD8+IL-2+ and CD8+IL-4+ TEMs decreased from baseline (Figure 5B). Numbers of CD4+IFN-gamma+ and CD8+IFN-gamma+ TEMs were low and did not change.

\section{IFN-Gamma Negative}

Subjects who were IFN-gamma negative had a decrease in total number of TEMs and $\mathrm{CD}^{+} \mathrm{IL}^{2+}+\mathrm{CD} 4+\mathrm{IL}-4+$ TEMs, CD8+IL-2+ and CD8+IL4+ TEMs from baseline

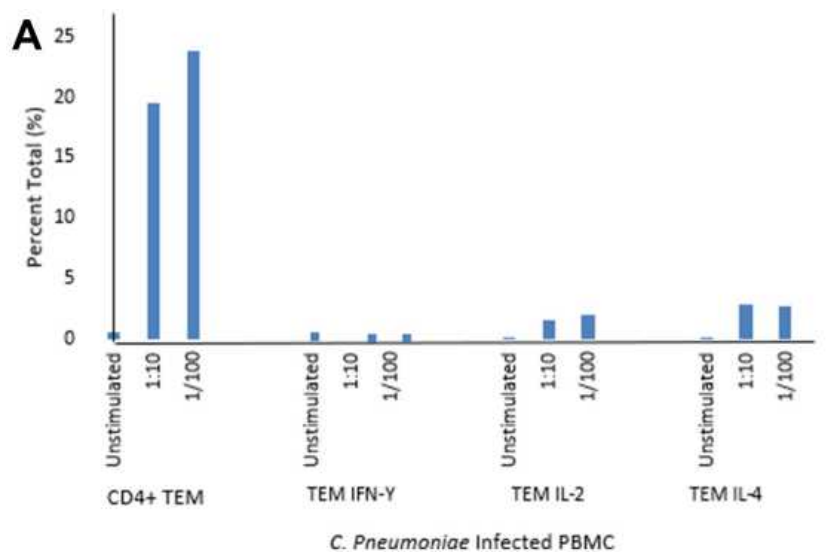

\section{Discussion}

In this study C. pneumoniae-induced PBMC IFN-gamma + responses increased numbers of CD4+ IL-2+ and CD4 + IL-4+ TEMs, while numbers of CD8+IL-2+ and CD8 +IL-4+ TEMs decreased. The observation of a combined IFN-gamma and CD4+ $\mathrm{T}$ cell memory response in healthy individuals may be associated with specific responses against $C$. pneumoniae antigens associated with persistent infection. Little is known about the role of C. pneumoniae-specific TEMs in humans; additional data are needed to provide an understanding of the role of C. pneumoniae-specific TEMs and the cytokines

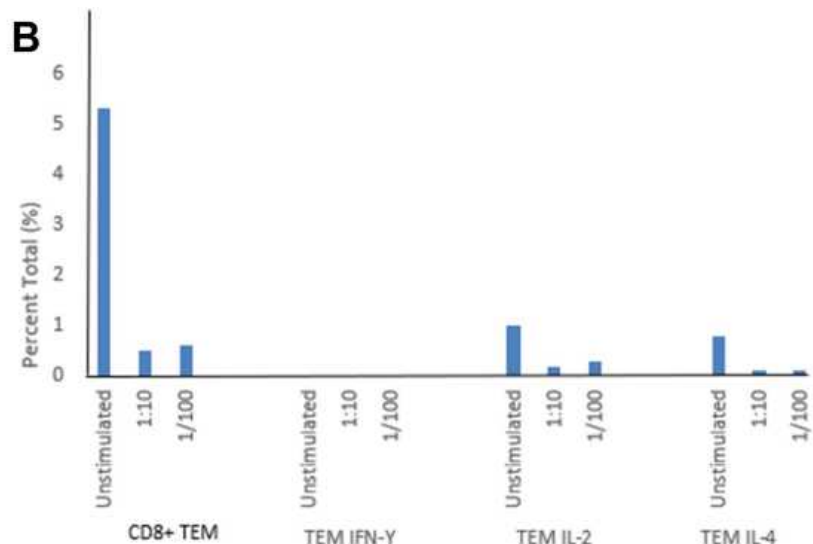

Figure 5 CD4+ and CD8+ TEMs stratified according to IFN- $\gamma$ levels in IFN- $\gamma$ positive subject. (A) CD4+, CD4+ IFN- $\gamma+$, CD4+IL-2+ and CD4+IL-4+ TEMs. (B) CD8+, CD8+ IFN- $\gamma+$, CD8+IL-2+ and CD8+ IL-4+ TEMs. See materials and methods. 

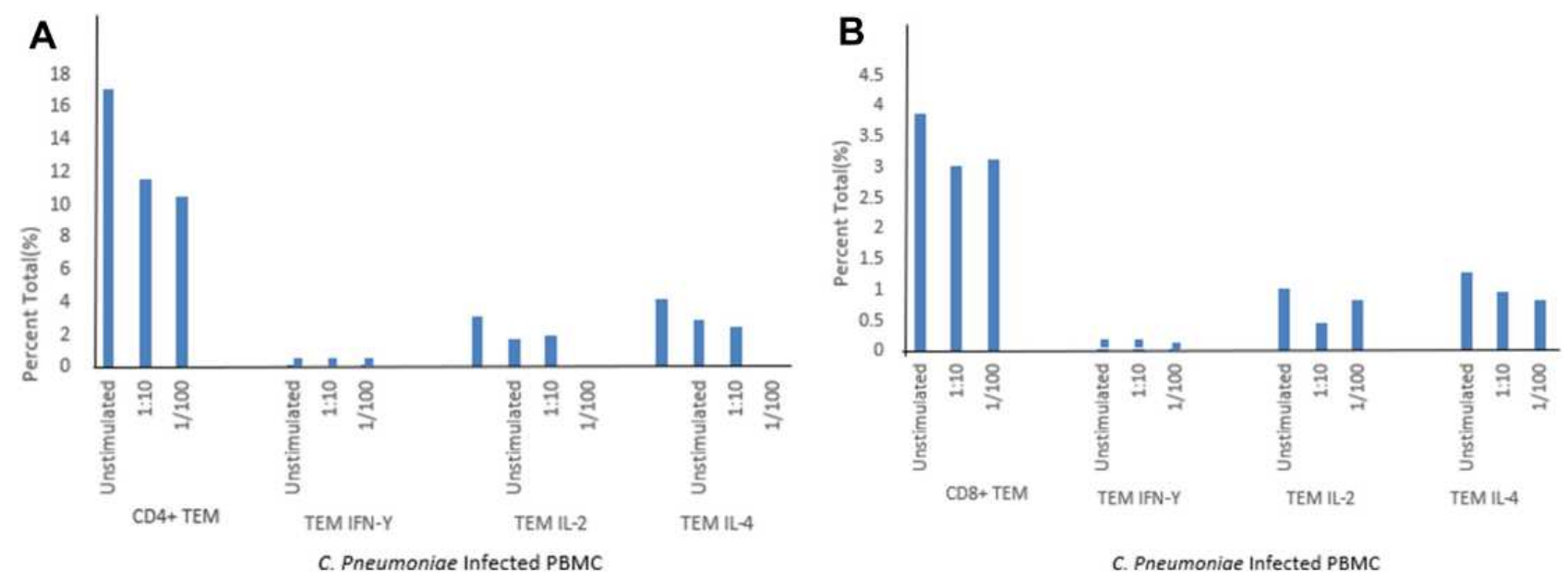

Figure 6 CD4+ and CD8+ TEMS stratified according to IFN- $\gamma$ levels in IFN- $\gamma$ negative subjects. (A) CD4+, CD4+ IFN- $\gamma+$, CD4+IL-2+ and CD4+IL-4+ TEMs. (B) CD8+, CD8+IFN- $\gamma+$, CD8+IL-2+ and CD8+IL-4+ TEMs. See materials and methods.

required for identification of past or persistent infection in mammalian cells.

Humoral and CMI contribute to protection against viral infections. ${ }^{31}$ The anti-viral effect of CMI is through virusspecific $\mathrm{CD} 4+$ and $\mathrm{CD} 8+\mathrm{T}$ cells by cytokine production and killing virus-infected cells. ${ }^{32}$ Virus-specific $\mathrm{CD}^{+}$T-cell responses against chronic viruses are characterized by secretion of interferon-gamma (Th1 type response). ${ }^{32}$ Virus-specific $\mathrm{CD}^{+} \mathrm{T}$-cell responses produce many factors, including IFNgamma, tumor necrosis factor (TNF)- $\alpha$, and macrophage inflammatory protein- $1 \beta$ (MIP-1 $\beta){ }^{32}$ During primary C. pneumoniae infection and reinfection, CD4+ and CD8+ $\mathrm{T}$ cells play a protective role in mouse models of infection. ${ }^{33-35}$ This observation may suggest development of C. pneumoniae-specific memory $\mathrm{T}$ cells. ${ }^{20}$ Virus-specific memory $\mathrm{T}$ cells have also been reported in other persistent infections (cytomegalovirus, varicella-zoster virus, EpsteinBarr virus and HIV). ${ }^{32}$

In the current study, C. pneumoniae infection led to a decrease in total numbers of CD8+TEM and CD8 $+\mathrm{CD} 154+$ cells, but numbers of CD4+TEM and CD4 $+\mathrm{CD} 154+$ cells did not change. In addition, numbers of TEM cells (CD4+IL-2+, CD8+ IL-2+) decreased. However, numbers of TEM cells (CD4+IL-4+, CD8+IL-4 $+)$ did not change in our stimulation system. This may indicate the low prevalence of $C$. pneumoniae-specific circulating memory cells in our subjects. Another possible explanation may be that $C$. pneumoniae inhibits $C$. pneumoniaespecific CD8+ memory T cells; these cells might be altered during infection and become functionally defective. However, IFN-gamma secretion has been reported as a necessary component for controlling C. pneumoniae infection. Thus, overall, our data argue that CD4+TEM and CD4+ CD154+ $\mathrm{T}$ cells are necessary for sustaining $\mathrm{T}$ cell effector activity in activated Th1 cells. Our studies are in agreement with earlier studies of Bunk et al who reported that Chlamydia pneumoniae-induced memory CD4 $+\mathrm{T}$ cell responses involving the production of IFN-gamma and/or IL-2 were found in PBMC of healthy humans without acute respiratory infection. ${ }^{20}$ When cells were restimulated with C. pneumoniae, the majority of cytokine-producing CD4+ $\mathrm{T}$ cells expressed CD154, a marker for CD4+ T cells activated with antigen. ${ }^{20}$ Studies of others also demonstrated that $\mathrm{CD} 154$ is a specific marker of $\mathrm{Ag}$-specific $\mathrm{CD}^{+} \mathrm{T}$ cells producing IFN- $\gamma$, IL-2, or TNF- $\alpha .{ }^{36,37}$

IFN-gamma contributes to protective immunity against infectious diseases. ${ }^{38}$ However, the role of IFN-gamma on the protective immunity to influencing TEM expression and activity in effector $\mathrm{CD} 4+$ or $\mathrm{CD} 8+\mathrm{T}$ cells during C. pneumoniae infection is unclear. Our next observation was that when subjects were stratified according to IFNgamma+ status, subjects who were IFN-gamma negative had a decrease in total number of TEMs and CD4+IL-2+, CD4+IL-4+ TEMs, CD8+IL-2+ and CD8+IL-4+ TEMs. Subjects who were IFN-gamma positive had an increase in CD4+ IL-2+ and CD4+IL-4+ TEMs, while numbers of CD8 + IL-2+ and CD8+ IL-4+ TEMs decreased. These findings are suggestive of an important role for CD4+ and CD8 + TEMs in IFN-gamma positive producing PBMC in response to C. pneumoniae infection. It could be speculated that these TEM cells and cytokines generate multifunctional inflammatory responses against $C$. pneumoniae infection and that specific TEMs have the potential to control cytokineinduced inflammatory responses in the presence of infection 
or during recovery from infection. In asymptomatic persons, the presence of CD4+TEMs and IFN-gamma secretion by PBMC may indicate persistent infection because effector memory cells should disappear from peripheral blood once someone has recovered from acute infection.

In infectious diseases, toll like receptors (TLRs) induced by IFN-gamma help phagocytic cells recognize pathogen. ${ }^{38}$ IFN-gamma contributes to CD4+ T cell differentiation to a Th1-type phenotype by activating signal transducer and activator of transcription (STAT) proteins that increase the $\mathrm{T}$ cell response to IL-2. ${ }^{39}$ It is well established that control and clearance of bacterial and viral infections depend on antigen-specific IFN-gamma secreting T helper cells. ${ }^{40,41}$

There are limitations that should be mentioned including small sample size of the study population. Small sample size may contribute to decreased power and increased type II error; future larger studies may help verify the findings of this study. Other limitations include the presence of only one subject that was IFN-gamma positive. This is a preliminary pilot study; future studies will include more subjects with positive IFN-gamma responses to reach proper conclusions.

In this preliminary study, C. pneumoniae-induced PBMC increased CD4+ but not CD8+ TEM responses in asymptomatic subjects characterized by production of high levels of IFN-gamma. These results have important clinical implications for use of this IFN-gamma assay as a potential biomarker of persistent infection in humans.

\section{Abbreviations}

C. pneumoniae,Chlamydia pneumoniae; PBMC, peripheral blood mononuclear cells; TEM, T effector memory cell.

\section{Data Sharing Statement}

Upon request from authors.

\section{Ethics Approval}

This study was approved by the SUNY Downstate Medical Center Institutional Review Board (Brooklyn, NY) and human studies adhered to the World Medical Association Declaration of Helsinki. Written informed consent for participation and publication was obtained from all participants.

\section{Consent to Participate}

Written consent to participate was obtained.

\section{Consent for Publication}

Written consent for publication was obtained.

\section{Acknowledgments}

The abstract from this article was accepted for oral presentation at the annual AAAAI meeting March 2020 in Philadelphia, PA. The meeting was canceled due to the COVID-19 pandemic. The published abstract reference is listed below.

Shidid S, Kohlhoff S, Norowitz Y, et al. Chlamydia pneumoniae decreases CD4+ and CD8+ T effector IL-2 responses in stimulated peripheral blood mononuclear cells in non-asthmatic subjects. J Allergy Clin Immunol 2020; 145(2): AB163.

Earlier pilot studies in our laboratory using similar methods was published as abstract and presented as poster presentation at the AAAAI/WAO Joint Congress meeting March 2018, Orlando, FL. The published abstract reference is listed below.

Norowitz YM, Kohlhoff K, Banniettis N, Hammerschlag MR, Smith-Norowitz TA. Chlamydia pneumoniae enhances CD4+ and CD8+ effector memory cell IL-2 and IL-4 responses in stimulated peripheral blood mononuclear cells in human subjects. J Allergy Clin Immunol 2018; 141 (2): AB123.

\section{Author Contributions}

All authors made a significant contribution to the work reported, whether that is in the conception, study design, execution, acquisition of data, analysis and interpretation, or in all these areas; took part in drafting, revising or critically reviewing the article; gave final approval of the version to be published; have agreed on the journal to which the article has been submitted; and agree to be accountable for all aspects of the work.

\section{Funding}

This research did not receive any specific grant from funding agencies in the public, commercial, or not-forprofit sectors.

\section{Disclosure}

The authors report no conflicts of interest in this work. 


\section{References}

1. Hammerschlag MR, Kohlhoff SA, Gaydos CA. Chlamydia pneumoniae. In: Mandell GL, Bennett JE, Dolin R, editors. Principles and Practice of Infectious Diseases. 8th ed. Philadelphia, PA: Elsevier, Inc.; 2014:2174-2182.

2. Johnston SL, Martin RJ. Chlamydophila pneumoniae and Mycoplasma pneumoniae a role in asthma pathogenesis? $\mathrm{Am}$ $J$ Respir Crit Care Med. 2005;172:1078-1089. doi:10.1164/rccm.20 0412-1743PP

3. Emre U, Roblin PM, Gelling M, et al. The association of Chlamydia pneumoniae infection and reactive airway disease in children. Arch Pediatr Adolesc Med. 1994;148:727-731. doi:10.1001/archpedi. 1994.02170070065013

4. Hammerschlag MR, Chirgwin K, Roblin PM, et al. Persistent infection with Chlamydia pneumoniae following acute respiratory illness. Clin Infect Dis. 1992;14:178-182. doi:10.1093/clinids/14.1.178

5. Martin RJ, Kraft M, Chu HW, et al. A link between chronic asthma and chronic infection. J Allergy Clin Immunol. 2001;107:595-601. doi:10.1067/mai.2001.113563

6. Ikezawa S. Prevalence of Chlamydia pneumoniae in acute respiratory tract infection and detection of anti-Chlamydia pneumoniae-specific $\mathrm{IgE}$ in Japanese children with reactive airway disease. Kurume Med J. 2001;48(2):165-170. doi:10.2739/kurumemedj.48.165

7. Kohlhoff SA, Hammerschlag MR. Treatment of chlamydial infections: 2014 update. Expert Opin Pharmacother. 2015;16:205-212. doi:10.1517/14656566.2015.999041

8. Khan AA, Slifer TR, Araujo FG, et al. Effect of clarithromycin and azithromycin on production of cytokines by human monocytes. Int J Antimicrobial Agents. 1999;11:121-132. doi:10.1016/S09248579(98)00091-0

9. Emre U, Sokolovskaya N, Roblin PM, et al. Detection of anti-Chlamydia pneumoniae $\operatorname{IgE}$ in children with reactive airway disease. J Infect Dis. 1995;172:265-267. doi:10.1093/infdis/172.1. 265

10. Kohlhoff SA, Joks R, Kamath T, et al. Chlamydophila pneumoniae mediated IgE production by peripheral blood mononuclear cells of allergic asthmatics is suppressed by doxycycline. J Allergy Clin Immunol. 2007;119(2):p525. doi:10.1016/j.jaci.2006.12.633

11. Beatty WL, Morrison RP, Byrne GL. Persistent chlamydiae: from cell culture to a paradigm form chlamydial pathogenesis. Microbiol Rev. 1994;58:689-694. doi:10.1128/MR.58.4.686-699.1994

12. Kutlin A, Flegg C, Stenzel D, et al. Ultrastructural study of Chlamydia pneumoniae in a continuous infection model. $J$ Clin Microbiol. 2001;39:3721-3723. doi:10.1128/JCM.39.10.3721-3723. 2001

13. Kohlhoff SA, Kutlin A, Riska P, et al. In vitro models of acute and long-term continuous infection of human respiratory epithelial cells with Chlamydophila pneumoniae have opposing effects on host cell apoptosis. Microb Pathogen. 2008;44:34-42. doi:10.1016/j.micpath. 2007.08.003

14. Chirgwin K, Roblin PM, Gelling M, et al. Infection with Chlamydia pneumoniae in Brooklyn. $J$ Infect Dis. 1991;163:757-761. doi:10.1093/infdis/163.4.757

15. Halme S, Latvala J, Karttunen R, et al. Cell-mediated immune response during primary Chlamydia pneumoniae infection. Infect Immun. 2000;68:7156-7158. doi:10.1128/IAI.68.12.7156-7158.2000

16. Smith-Norowitz TA, Chotikanatis K, Erstein DP, et al. Chlalmydia pneumoniae enhances the Th2 profile of stimulated peripheral blood mononuclear cells from asthmatic patients. Hum Immunol. 2016;77:382-388. doi:10.1016/j.humimm.2016.02.010

17. Smith-Norowitz TA, Weaver D, Chorny V, et al. Chlamydia pneumoniae induces interferon gamma responses in peripheral blood mononuclear cells in children with allergic asthma. Scan J Immunol. 2017;86:59-64. doi:10.1111/sji.12561
18. Igietseme JU, Ramsey KH, Magee DM, et al. Resolution of murine chlamydial genital infection by the adoptive transfer of a biovar-specific, Th1 lymphocyte clone. Reg Immunol. 1993; 5:317-324.

19. Holland MJ, Bailey RL, Conway DJ, et al. T-helper type 1 (Th1)/Th2 profiles of peripheral blood mononuclear cells (PBMC); responses to antigens of Chlamydia trachomatis in subjects with severe trachomatous scarring. Clin Exp Immunol. 1996;105:429-435. doi:10.1046/ j.1365-2249.1996.d01-792.x

20. Bunk S, Schaffert H, Schmid B, et al. Chlamydia pneumoniae-induced memory CD4+ T-cell activation in human peripheral blood correlates with distinct antibody response patterns. Clin Vaccine Immunol. 2010;17:705-712. doi:10.1128/CVI.00209-09

21. Tonaco MM, Moreira JD, Nunes FFC, et al. Evaluation of profile and functionality of memory $\mathrm{T}$ cells in pulmonary tuberculosis. Immunol Lett. 2017;192:52-60. doi:10.1016/j.imlet.2017.10.014

22. Cowen MK, Wakefield DB, Cloutier MM. Classifying asthma severity: objective versus subjective measures. $J$ Asthma. 2007;44:711-715. doi:10.1080/02770900701595576

23. Smith-Norowitz TA, Weaver D, Norowitz YM, et al. Doxycycline suppresses Chlamydia pneumoniae induced interferon gamma responses in peripheral blood mononuclear cells in children with allergic asthma. J Infect Chemother. 2018;24:470-475. doi:10.1016/ j.jiac.2018.02.004

24. Wang SP, Grayston JT. Microimmunofluorescence serological studies with the TWAR organism. In: Oriel D, Ridgeway G, editors. Chlamydial Infections: Proceedings of the Sixth International Symposium on Human Chlamydial Infections. Cambridge: Cambridge University Press; 1986:329-332.

25. Roblin PM, Dumornay W, Hammerschlag MR. Use of HEp-2 cells for improved isolation and passage of Chlamydia pneumoniae. J Clin Microbiol. 1992;30:1968-1971. doi:10.1128/JCM.30.8.1968-1971.1 992

26. Dzhindzhikhashvili MS, Joks R, Smith-Norowitz TA, et al. Doxycycline suppresses Chlamydia pneumoniae-mediated increases in ongoing immunoglobulin $\mathrm{E}$ and interleukin-4 responses by peripheral blood mononuclear cells of patients with allergic asthma. J Antimicrob Chemother. 2013;68:2363-2368. doi:10.1093/jac/dkt179

27. Apfalter P, Barousch W, Nehr M, et al. Comparison of a new quantitative ompA-based real-time PCR TaqMan assay for detection of Chlamydia pneumoniae DNA in respiratory specimens with four conventional PCR assays. J Clin Microbiol. 2003;41:592-600. doi:10.1128/JCM.41.2.592-600.2003

28. Waring AL, Halse TA, Csiza CK, et al. Development of a genomics-based PCR assay for detection of Mycoplasma pneumoniae in a large outbreak in New York State. $J$ Clin Microbiol. 2001;39:1385-1390. doi:10.1128/JCM.39.4.1385-1390.2001

29. Smith-Norowitz TA, Bluth MH, Drew H, et al. Effect of minocycline and doxycycline on IgE responses. Ann Allergy Asthma Immunol. 2002;89:172-179. doi:10.1016/S1081-1206(10)61934-5

30. Shidid S, Kohlhoff S, Norowitz Y, et al. Chlamydia pneumoniae decreases CD4+ and CD8+ T effector IL-2 responses in stimulated peripheral blood mononuclear cells in non-asthmatic subjects. $J$ Allergy Clin Immunol. 2020;145(2):AB163. doi:10.1016/j.jaci. 2019.12.430

31. Doherty PC, Christensen JP. Accessing complexity, the dynamics of virus-specific T cell responses. Annu Rev Immunol. 2000;18:561-592. doi:10.1146/annurev.immunol.18.1.561

32. Harari A, Dutoit V, Cellerai C, Bart PA, Du Pasquier RA, Pantaleo G. Functional signatures of protective antiviral T-cell immunity in human virus infections. Immunol Rev. 2006;211:236-254. doi:10.1111/j.0105-2896.2006.00395.x

33. Rothfuchs AG, Kreuger MR, Wigzell H, et al. Macrophages, CD4 + or CD8 + cells are each sufficient for protection against Chlamydia pneumoniae infection through their ability to secrete IFN- $\gamma$. J Immunol. 2004;172:2407-2415. doi:10.4049/jimmunol.172.4.2407 
34. Rottenberg ME, Gigliotti Rothfuchs AC, Gigliotti G, et al. Role of innate and adaptive immunity in the outcome of primary infection with Chlamydia pneumoniae as analyzed in genetically modified mice. J Immunol. 1999;162:2829-2836.

35. Pentilla JM, Anttila M, Puolakkainen M, et al. Local immune responses to Chlamydia pneumoniae in the lungs of BALB/mice during primary infection and reinfection. Infect Immun. 1998;66:5113-5118. doi:10.1128/IAI.66.11.5113-5118.1998

36. Frentsch M, Arbach O, Kirchhoff D, et al. Direct access to CD4+ $\mathrm{T}$ cells specific for defined antigens according to CD154 expression. Nat Med. 2005;11:1118-1124. doi:10.1038/nm1292

37. Chattopadhyay PK, Yu J, Roederer M. A live-cell assay to detect antigen-specific $\mathrm{CD}^{+}{ }^{+} \mathrm{T}$ cells with diverse cytokine profiles. Nat Med. 2005;11:1113-1117. doi:10.1038/nm1293

38. Borges da Silva H, Fonseca R, Alvarez JM, et al. IFN- $\gamma$ priming effects on the maintenance of effector memory CD4 $+\mathrm{T}$ cells and on phagocyte function: evidences from infectious diseases. J Immunol Res. 2015;2015:202816. doi:10.1155/2015/202816
39. Matikainen S, Sareneva T, Ronni T, et al. Interferon- $\alpha$ activates multiple STAT proteins and upregulates proliferation-associated IL-2R $\alpha$, cmyc, and pim-1 genes in human T cells. Blood. 1999;93:1980-1991. doi:10.1182/blood.V93.6.1980.406k20 19801991

40. Stubbe M, Vanderheyde N, Goldman M, et al. Antigen-specific central memory CD4 $+\mathrm{T}$ lymphocytes produce multiple cytokines and proliferate in vivo in humans. J Immunol. 2006;177:8185-8190. doi:10.4049/jimmunol.177.11.8185

41. Shtrichman R, Samuel CE. The role of gamma interferon in antimicrobial immunity. Curr Opin Microbiol. 2001;4:251-259. doi:10.1016/S1369-5274(00)00199-5

\section{Publish your work in this journal}

The Journal of Blood Medicine is an international, peer-reviewed, open access, online journal publishing laboratory, experimental and clinical aspects of all aspect pertaining to blood based medicine including but not limited to: Transfusion Medicine; Blood collection, Donor issues, Transmittable diseases, and Blood banking logistics; Immunohematology; Artificial and alternative blood based therapeutics; Hematology; Biotechnology/nanotechnology of blood related medicine; Legal aspects of blood medicine; Historical perspectives. The manuscript management system is completely online and includes a very quick and fair peer-review system. Visit http://www.dovepress.com/testimonials.php to read real quotes from published authors. 